\title{
BIOCHEMICAL STUDIES OF DIFFERENT PARTS OF AFZELIA AFRICANA SMITH
}

\author{
Okeke Clement U., Okeke Philomena N., Iroka Finian C. and Orji May E. \\ Department of Botany, Nnamdi Azikiwe University, Awka. P. M. B 5025 Anambra State. \\ Nigeria
}

*Corresponding author: np.okeke@unizik.edu.ng; okekeprisca36@gmail.com

Cite this article:

Okeke C.U., Okeke P.N., Iroka F.C., Orji M.E. (2021), Biochemical Studies of Different Parts of Afzelia Africana Smith. African Journal of Agriculture and Food Science 4(4), 11-24. DOI: $10.52589 / A J A F S-$ 8T8ZHZTN.

\section{Manuscript History}

Received: 16 June 2021

Accepted: 14 July 2021

Published: 3 Oct 2021

Copyright $\left({ }^{\circ} 2020\right.$ The Author(s). This is an Open Access article distributed under the terms of Creative Commons AttributionNonCommercial-NoDerivatives 4.0 International (CC BY-NC-ND 4.0), which permits anyone to share, use, reproduce and redistribute in any medium, provided the original author and source are credited.
ABSTRACT: Phytochemical and proximate analysis was carried out on the seed, leaf, stem bark, stem, root bark and root of Afzelia Africana plant. This analysis revealed that phytochemical constituents were mostly predominant in the leaf and lower in other parts of the plant. Steroid was high in the root $(0.49 \pm 0.01)$ and lower in the stem $(0.04 \pm 0.01)$. Phytate content was high in the seed $(0.40 \pm 0.03)$ and lower in the stem. Carbohydrate, protein, fats, ash and moisture content were high in the seed. Fibre was high in the stem $(61.1 \pm 0.23)$ and lower in the seed (3.61 \pm 0.06$)$. Vit. C (ascorbic acid) was the highest vitamin component in all the plant parts with leaf being the highest $(12.69 \pm 1.02)$ and root having the lowest $(2.64 \pm 1.24)$. The stem has the lowest content of Vit. A, Vit. $\mathrm{B}_{2}$, and Vit. $\mathrm{B}_{3}$. The seed has the highest calcium content $(188.80 \pm 5.54)$ while the leaf has the lowest $(28.84 \pm 0.25)$. Stem bark has the highest magnesium content $(10.08 \pm 0.94)$ and lowest in the root $(4.96 \pm 0.14)$. Potassium and phosphorus were high in the leaf $(368.67 \pm 3.06)$ and low in the stem. Sodium was high in the seed $(11.63 \pm 0.40)$ and lower in the root $(5.23 \pm 0.23)$. This study shows that the seed of Afzelia africana has the highest biochemical content and could serve as a good food supplement for man and livestock. The presence of phytate is known to induce mineral-related deficiency, its consumption also provides protection against a variety of cancers via its antioxidant properties.

KEYWORDS: Phytochemical, Mineral, Vitamin, Afzelia africana, seed, leaf, stem bark, stem, root bark and root 


\section{INTRODUCTION}

Afzelia africana belongs to the family fabaceae. ${ }^{(14)}$ It is a very attractive medium sized tree. The stem has relatively thick, unequal buttresses with a light concave profile, generally $1-15 \mathrm{~m}$ tall. The fruits are flat, hard, dark brown or black pods. Each pod contains several oblong black bean-shaped seeds with bright orange aril. It survives harsh weather conditions. ${ }^{(19)}$ Several studies on the plant showed that it contained vital nutrients such as protein, fat, micro and macro minerals.

The quest for plants with medicinal properties continues to receive attention as scientist survey plants, particularly of ethno-botanical significance, for a complete range of biological activities, which range from antibiotic to antitumor. Thus, plants have provided western medicine with an abundance of drugs and treatments for a variety of health problems. ${ }^{17 ; 5)}$ Medicinal plants and herbs are of great importance to health and each plant has its own nutrient composition besides having pharmacological importance. Therefore, study is designed to determine the phytochemicals, vitamins and mineral composition of the seed, leaf, stem bark, root bark and root of Afzelia Africana.

\section{MATERIALS AND METHODS}

\section{Plant collection:}

The plant parts of Afzelia Africana were obtained from Amuda Isuochi, Umunneochi Local Government Area, Abia State, Nigeria and were identified by Prof. C. U. Okeke, a plant taxonomist in the department of Botany, Nnamdi Azikiwe University, Awka.

\section{Preparation of samples}

The stem and roots were manually peeled with the aid of matchet to separate the bark from the woody parts. The harvested seeds, leaves, stem, bark, root, and root bark were oven dried at the temperature of $65^{\circ} \mathrm{C}$. The dried samples were grounded for analysis.

\section{Quality Phytochemical Screening}

Phytochemical screening was conducted on the samples to determine the presence or absence of phytochemicals of interest as saponin, flavonoid, tannin, phenols, alkaloid, anthocyanin, steroid, iridoids etc

\section{Test for Saponin}

This was done using the saponin froth test. ${ }^{(11)}$ Extract of each sample (2ml) was mixed with $5 \mathrm{ml}$ of distilled water in a tube. The mixture was shaken vigorously. The presence of a steady froth indicates the presence of saponin.

\section{Test for Flavonoid}

The presence of flavonoid was determined by the acid-alkaline test. ${ }^{(11)}$ Extract of each sample $(2 \mathrm{ml})$ was dispersed into a test tube and a few drops of ammonia $\left(\mathrm{NH}_{3}\right)$ were added to it. The formation of yellow coloration indicates the presence of flavonoid. 


\section{Test for Tannin}

$5 \mathrm{~g}$ of each sample was dispensed into $50 \mathrm{ml}$ of distilled water. The mixture was left for some hours, then filtered through Whatman No. 42 filter paper. $2 \mathrm{ml}$ of filtrate was measured into a test tube and 2 drops of dilute ferric chloride solution was added to the mixture, forming a very dark precipitate indicating the presence of tannin.

\section{Test for Steroids}

This was done using the Lieberman-Burchard test. ${ }^{(11)}$ Acetic anhydride (2ml) was added to $5 \mathrm{ml}$ of each plant sample extract, followed by $2 \mathrm{ml}$ of conc. sulphuric acid down the wall of the test tube to form a layer underneath. The formation of a reddish-violet, brown or green color indicates the presence of steroids.

\section{Test for Phenol}

The extract $(2 \mathrm{ml})$ was mixed with $5 \mathrm{ml}$ of distilled water. The mixture was heated and filtered. Neutral ferric chloride was added to the filtrate and observed for green, blue or black coloration.

\section{Test for Alkaloid}

The presence of alkaloid in the test sample was investigated using the Mayer's colorimetric method. ${ }^{(11)}$ Ethanolic extract of the sample was obtained by shaking $2 \mathrm{~g}$ in $20 \mathrm{ml}$ of ethanol for $30 \mathrm{~min}$ before filtration. The filtrate was used as extract. $2 \mathrm{ml}$ of the extract was mixed with a few drops of Mayer's reagent in a test tube. The formation of an orange precipitation showed the presence of alkaloid.

\section{Determination of Quantitative Phytochemicals}

\section{Determination of Alkaloid}

This was done by an alkaline ppt gravimetric method. ${ }^{(11)} 5 \mathrm{~g}$ of each sample was dispersed into $50 \mathrm{ml}$ of $10 \%$ acetic acid sol in ethanol. The mixture was shaken and allowed to stand at room temp for $4 \mathrm{hrs}$. It was filtered using Whatman No. 42 grade of filter. The filtrate was concentrated to a quarter of its original volume by evaporation over a steam bath. Alkaloid in the extract was precipitated by drop wise addition of $\mathrm{NH}_{4} \mathrm{OH}$ until full turbidity was obtained. The alkaloid ppt was recovered using a weighted filter paper, and washed with $1 \%$ ammonia solution, dried in the oven at $80^{\circ} \mathrm{C}$ for an hour. It was cooled in a desiccator and reweighed. By weight difference, the weight of the alkaloid was determined and expressed as a percentage of the sample analyzed, using the formula alkaloid $\%=\mathrm{W}_{2}-\mathrm{W}_{1} * 100 / 1$. Where; $\mathrm{W}_{1}=$ weight of sample. $\mathrm{W}_{2}=$ weight of empty filter paper

\section{Determination of Flavonoid}

$.10 \mathrm{~g}$ of the sample was extracted repeatedly into $100 \mathrm{ml}$ of $80 \%$ aqueous methanol at room temperature. The whole solution was filtered, the filtrate transferred into a crucible and evaporated to dryness over a water bath and weighed. The weight was calculated as Flavonoid $\%=\mathrm{W}_{2}-\mathrm{W}_{1} /$ Weight of the sample $\times 100 / 1$. Where $\mathrm{W}_{1}=$ weight of empty filter paper. $\mathrm{W}_{2}=$ weight of paper + flavonoid ppt ${ }^{(3)}$ 


\section{Determination of Saponin}

This was done using the Double solvent extraction gravimetric method. ${ }^{(11)} 5 \mathrm{~g}$ of the powdered sample was weighed out and mixed with $50 \mathrm{ml}$ of $20 \%$ aqueous ethanol solution. The mixture was heated in a water bath for $90 \mathrm{mins}$ at $55^{\circ} \mathrm{C}$. It was filtered and the residue re-extracted with $50 \mathrm{ml}$ of $20 \%$ ethanol, both extracts were combined together. The combined extracts were reduced to $40 \mathrm{ml}$ over a water bath at $90^{\circ} \mathrm{C}$. The concentration was transferred into a 250 separating funnel where $40 \mathrm{ml}$ of diethyl ether was added and shaken vigorously. Separation was by partition during which the aqueous layer was recovered and the ether layer discarded. Re-extraction by partition was done repeatedly until the aqueous layer became clear in color. The saponins were extracted with $60 \mathrm{ml}$ of normal butanol. The combined n-butanol extract was washed with $5 \%$ aqueous $\mathrm{NaCl}$ sol. and was evaporated to dryness in a pre-weighed evaporating dish. It was dried at $60^{\circ} \mathrm{C}$ in the oven and weighed. The experiment was repeated twice so as to get an average. The saponin content was determined and expressed as a percentage of the weight analysed. Given by the formula saponin $\%=\mathrm{W}_{2}-\mathrm{W}_{1} * 100 / 1$. Where; $\mathrm{W}_{1}=$ weight of sample. $\mathrm{W}_{2}=$ weight of empty filter paper

\section{Determination of Tannin}

The tannin content was determined using the Folin-Dennis spectrophotometric method. (27) About $1 \mathrm{~g}$ of the sample was dispersed in $10 \mathrm{ml}$ of distilled water and was shaken. This was left to stand for $30 \mathrm{mins}$ at room temperature while being shaken every 5 mins. It was then centrifuged and the extract was obtained. $2.5 \mathrm{ml}$ of the supernatant was dispersed into a $50 \mathrm{ml}$ volumetric flask. Similarly, $2.5 \mathrm{ml}$ of standard tannic acid solution was dispersed into a separate $50 \mathrm{ml}$ flask. $1 \mathrm{ml}$ of folin-denis reagent was measured into each flask, followed by $2.5 \mathrm{ml}$ of saturated $\mathrm{Na}_{2} \mathrm{CO}_{3}$ solution. The mixture was diluted and incubated for 90 mins at room temperature. The absorbance was measured at $250 \mathrm{~nm}$ in a UV VIS spectrophotometer, readings were taken with the reagent blank at zero. The tannin content was given as tannin $\%=100 / \mathrm{W} \times \mathrm{A}_{\mathrm{n}} / \mathrm{A}_{\mathrm{s}} \times \mathrm{V}_{\mathrm{f}} / \mathrm{V}_{\mathrm{a}}$. Where $\mathrm{A}_{\mathrm{n}}=$ absorbance of test sample. $\mathrm{A}_{\mathrm{s}}=$ absorbance of standard solution. $\mathrm{C}=$ concentration of standard solution. $\mathrm{W}=$ weight of sample used. $\mathrm{V}_{\mathrm{f}}=$ total volume of extract. $\mathrm{V}_{\mathrm{a}}=$ volume of extract analyzed.

\section{Determination of Phenol}

The Follins method was used to determine the presence of Phenol. ${ }^{(27)} 0.2 \mathrm{~g}$ of each sample was dispersed in $10 \mathrm{ml}$ of methanol and shaken. It stood for $30 \mathrm{~min}$ at room temperature and was then filtered using Whatman filter paper. $1 \mathrm{ml}$ of each extract was placed in a test tube and $1 \mathrm{ml}$ of Follin's reagent with $5 \mathrm{nl}$ of distilled water. It was allowed at room temperature for 3-4 hrs so the color can form. The absorbance of the developed color was measured at $760 \mathrm{~nm}$ wavelength. The phenol content was calculated thus: \%Phenol $=100 / \mathrm{W} * \mathrm{Au} / \mathrm{As} * \mathrm{C} / 100 *$ $\mathrm{Vf} / \mathrm{Va} * \mathrm{D}$. Where $\mathrm{W}=$ weight of sample analyzed. $\mathrm{Au}=$ absorbance of test tube. As= absorbance of standard solution. $\mathrm{C}=$ conc. standard $(\mathrm{mg} / \mathrm{ml}) . \mathrm{Vf}=$ total filtrate volume. $\mathrm{Va}=$ volume of filtrate analyzed. $\mathrm{D}=$ dilution factor where applicable.

\section{Determination of Anthocyanins}

The total anthocyanin content was determined by the differential $\mathrm{pH}$ method ${ }^{(8)}$ based on the property of anthocyanin pigments to change the color. Two dilutions of the two samples were prepared, the first in $\mathrm{KCl}(0.025 \mathrm{M} \mathrm{pH} 1.0)$ and the second in a sodium acetate buffer $(0.4 \mathrm{M} \mathrm{pH}$ 
4.5) $\mathrm{pH}$ being adjusted with $\mathrm{HCl} 0.24$. After equilibrium at room temperature for $15 \mathrm{~min}$, the absorbance of two dilutions was read at $510 \mathrm{~nm}$ and $700 \mathrm{~nm} . \mathrm{A}=(\mathrm{A} 510-\mathrm{A} 700)_{\mathrm{pH}}-(\mathrm{A} 510-\mathrm{A} 700)_{\mathrm{pH} 4.5}$

\section{Determination of Hydrogen Cyanide (HCN)}

$5 \mathrm{~g}$ of each sample was dissolved in $50 \mathrm{ml}$ of distilled water in a conical flask which was left overnight and filtered the next day. $4 \mathrm{ml}$ of alkaline picrate was added to $1 \mathrm{ml}$ of the sample filtrate in a corked test tube and boiled in a water bath for $5 \mathrm{~min}$. After color development, the filtrate was read in a spectrophotometer at $490 \mathrm{~nm}$. Also, the absorbance of the blank contains $1 \mathrm{ml}$ of distilled water and $4 \mathrm{ml}$ of alkaline solution. Then the cyanide content was extrapolated using a standard curve. ${ }^{(26)}$

\section{Determination of Steroids}

A $0.5 \mathrm{~g}$ weight of each sample was dispersed in $100 \mathrm{ml}$ freshly distilled water and homogenized in a laboratory blender which is then filtered and the filtrate eluted with normal $\mathrm{NH}_{4} \mathrm{OH}$ solution at $\mathrm{pH} 9.2 \mathrm{ml}$ of the eluted sample was put in a test tube and mixed with $2 \mathrm{ml}$ of chloroform, $2 \mathrm{ml}$ of acetic anhydride and 2 drops of conc. $\mathrm{H}_{2} \mathrm{SO}_{4}$ was cautiously added to the mixture. Standard steroid solution was prepared and treated. The absorbance of standard and prepared samples were measured in a spectrophotometer at $420 \mathrm{~nm}$ wavelength, with the reagent blank at zero. The experiment was repeated to get an average. Steroid content was calculated as steroid $\%=100 / \mathrm{W} \times \mathrm{Au} / \mathrm{As} \times \mathrm{C} / 1000 \times \mathrm{V}_{\mathrm{f}} / \mathrm{V}_{\mathrm{a}}$. Where $\mathrm{W}=$ weight of sample analysed. $\mathrm{Au}=$ absorbance of test sample. As= absorbance of standard solution in $\mathrm{mg} / \mathrm{ml} . \mathrm{V}_{\mathrm{f}}=$ total volume of extract. $\mathrm{V}_{\mathrm{a}}=$ volume of extract analyzed. ${ }^{(24)}$

\section{Determination of Iridoid}

$5 \mathrm{~g}$ of each sample was extracted with $50 \mathrm{ml}$ of methanol for $5 \mathrm{hrs}$ at $40^{\circ} \mathrm{C}$ and evaporated to dryness. It was partitioned with $2 * 25 \mathrm{ml}$ of dichloromethane followed by further partitioning with $2 * 25 \mathrm{ml} \mathrm{n}$-butanol and the butanol fraction was collected into a weighted dish, evaporated to dryness and cooled in a desiccator before re-weighing. The crude iridoid content is given by \%iridiod: $100 *\left(\mathrm{~W}_{2} * \mathrm{~W}_{1}\right) / \mathrm{W}$. Where, $\mathrm{W}=$ weight of the sample analyzed. $\mathrm{W}_{1}=$ weight of empty dish. $\mathrm{W}_{2}=$ volume of the dish + dry iridoid extract. ${ }^{(30)}$

\section{Determination of Phytate}

The phytate content was determined by their $\mathrm{B}_{1}$ pyridine colorimetric method. ${ }^{(26)} 2 \mathrm{~g}$ of each sample was extracted with $50 \mathrm{ml}$ of dilute acid $(0.1 \mathrm{M} \mathrm{HCl})$ for 30 minutes. It was filtered, using whtaman No. 1 filtered paper. $0.5 \mathrm{ml}$ of the filtrate was treated with equal volume of $2-2$, dipyridine solution. Standard phytate solution $(0.5 \mathrm{mg} / \mathrm{ml}$ sodium phytate) was prepared and $1 \mathrm{ml}$ of it was treated with the di-pyridine solution. Both the sample extract and the standard phytate solutions were diluted to $50 \mathrm{ml}$ in a volume flask and their respective absorbance was read in a spectrophotometer at a wavelength of $510 \mathrm{~nm}$. \%phytate: 100/W*Au/As*C*Vf/Va. Where: $\mathrm{W}=$ weight of sample analyzed. $\mathrm{Au}=\mathrm{absorbance}$ of the sample extracted. As= absorbance of standard solution. $\mathrm{C}=$ concentration of standard solution. $\mathrm{Vf}=$ total volume of extract. $\mathrm{Va}=$ volume of extract analyzed. 


\section{Proximate analysis}

\section{Determination of Ash}

The furnace incineration gravimetric method ${ }^{(10)}$ was used. $5 \mathrm{~g}$ each of the processed samples was measured into a previously weighed porcelain crucible. The sample was burnt to ashes in a muffle furnace at $550^{\circ} \mathrm{C}$. It was then in a desiccator and weighed. The weight of ash obtained was calculated by difference and expressed as a percentage of the sample analyzed: \&ash= $\left(\mathrm{W}_{2}-\mathrm{W}_{1}\right) / \mathrm{W}^{*} 100 / 1$. Where, $\mathrm{W}=$ weight of the sample. $\mathrm{W}_{1}=$ weight of empty crucible. $\mathrm{W}_{2}=$ weight of crucible + ash.

\section{Determination of Crude fibre}

The Weeden method was employed. ${ }^{(2)} 5 \mathrm{~g}$ of the defatted sample was boiled in $200 \mathrm{ml}$ of $1.25 \%$ $\mathrm{H}_{2} \mathrm{SO}_{4}$ solution under reflux for $30 \mathrm{~min}$. The sample was washed with several portions of hot water using a two-fold muslin cloth to trap the particle, then transferred quantitatively back into the flask. $200 \mathrm{ml}$ of $1.25 \% \mathrm{NaOH}$ sol was added to it. Again, the sample was boiled for 30 min and washed with hot water. It was then transferred to a weighed porcelain crucible and dried in the oven at $105^{\circ} \mathrm{C}$ for an hour, cooled in a desiccator and reweighed. The loss in weight after incineration was used to determine the crude fibre content and expressed as percentage of the weight of the sample: \%crude fibre $=\left(\mathrm{W}_{2}-\mathrm{W}_{3}\right) / \mathrm{W}_{1} * 100 / 1$. Where, $\mathrm{W}_{1=}$ weight of sample. $\mathrm{W}_{2}=$ weight of crucible + sample after drying. $\mathrm{W}_{3}=$ weight of crucible + sample (after ashing).

\section{Determination of Fat}

Soxhlet extraction method was used in the determination of Fat. ${ }^{(23)} 5 \mathrm{~g}$ of each sample was wrapped with a weighted porous paper (Whatman filter paper No. 40). The wrapped samples were put in a soxhlet reflux flask. The flak was mounted into an oil extraction flask containing $300 \mathrm{mlbof}$ petroleum ether and boiled at $60^{\circ} \mathrm{C}$ boiling points. The vaporized solvent condensed into the reflux flask and siphons over when it fills up carrying extracted oil down the boiling flask. This cycle was allowed to go on uninterrupted for about $4 \mathrm{hrs}$. The defatted samples were brought out with the aid of forceps and further dried in the oven at $100^{\circ} \mathrm{C}$ for $1 \mathrm{hr}$, cooled in a desiccator and weighed. The fat content was determined by weight difference of each sample and expressed as percentage of each weight sample as: \%fat $=\left(\mathrm{W}_{2}-\mathrm{W}_{3}\right) /\left(\mathrm{W}_{2}-\mathrm{W}_{1}\right)^{*} 100 / 1$. Where, $\mathrm{W}_{1}=$ weight of empty filtered paper. $\mathrm{W}_{2}=$ weight of paper + sample before defatting. $\mathrm{W}_{3}=$ weight of paper + sample after defatting and drying.

\section{Determination of Moisture content}

The moisture content was determined by the gravimetric method. ${ }^{(4)} 5 \mathrm{~g}$ of the fresh sample was put in a weighted moisture can and dried in the oven at $105^{\circ} \mathrm{C}$ for 3 hours, cooled in a desiccator and weighed. The weight was recorded and the sample returned in the oven for further drying. The process was repeated until a constant weight was obtained. By weight difference, the moisture loss was determined and expressed as a percentage of the sample weight analyzed. $\%$ Moisture $=\left(\mathrm{W}_{2}-\mathrm{W}_{3}\right) /\left(\mathrm{W}_{2}-\mathrm{W}_{1}\right)^{*} 100 / 1$. Where, $\mathrm{W}_{1}=$ weight of empty moisture can. $\mathrm{W}_{2}=$ weight of moisture can + sample before drying. $\mathrm{W}_{3}=$ weight of moisture can + sample after drying to constant weight. 


\section{Determination of Crude protein}

The protein content of each of the samples was determined by the Kjeldahl method. ${ }^{(7)}$ The total was determined and multiplied by the factor 6.38 to obtain the protein content. $1 \mathrm{ml}$ of each sample was mixed with $10 \mathrm{ml}$ of conc. sulphuric acid in a kjeldahl digestion flask. A tablet of selenium catalyst was added to it and the mixture was digested by heating in a fume cupboard until a clear solution was obtained. Each of the digest was carefully transferred to a $100 \mathrm{ml}$ volumetric flask and made up to the mark with distilled water. A $10 \mathrm{ml}$ of each digest was mixed with an equal volume of $45 \% \mathrm{NaOH}$ sol in a kjeldahl distilling unit. The mixture was distilled and the distillate collected into $10 \mathrm{ml}$ of $4 \%$ boric acid containing 3 drops of mixed indicator (bromocresol green and methyl red). A total of $50 \mathrm{mls}$ distillate was collected and titrated against $0.02 \mathrm{~N} \mathrm{H}_{2} \mathrm{SO}_{4}$ from green to deep red end point. A reagent blank was also digested, distilled and titrated. The $\mathrm{N}_{2}$ and protein content was calculated as $\mathrm{N}_{2} \%=100 / \mathrm{W} *$ $(\mathrm{N} * 14) / 1000 * \mathrm{~V}_{\mathrm{f}} / \mathrm{V}_{\mathrm{a}} * \mathrm{~T}-\mathrm{B}$. Where: $\mathrm{N}=$ normality of titrant $\left(\mathrm{H}_{2} \mathrm{SO}_{4}\right) . \mathrm{V}_{\mathrm{f}}=$ total volume of digestion. $\mathrm{V}_{\mathrm{a}}=$ volume of digest distilled. $\mathrm{T}=$ titre volume of sample. $\mathrm{B}=$ titre value of reagent blank.

\section{Determination of Minerals}

The mineral content of the samples were determined by the dry ash acid extraction method. ${ }^{(6)}$ $5 \mathrm{~g}$ of each sample was burnt to ashes in a muffle furnace at $50^{\circ} \mathrm{C}$. The resulting ash was dissolved in $10 \mathrm{ml}$ of $2 \mathrm{M} \mathrm{HCl}$ solution and diluted to $100 \mathrm{ml}$ in a flask using distilled water and filtered. The filtrate was used for the mineral analysis.

\section{Determination of Calcium and Magnesium}

This was carried out by the versenate EDTA complexometric titrimetric method. 20ml portion of each extract was dispersed into a conical flask and treated with inches of masking agents (hydroxylamine hydrochloride, sodium cyanide and sodium potassium ferrocyanide). The flask was shaken and the mixture dissolved. $20 \mathrm{ml}$ of ammonia was added to it to raise the $\mathrm{p}^{\mathrm{H}}$ to 10.00 (a point at which both calcium and magnesium form complexes with EDTA). The mixture was titrated against $0.02 \mathrm{~N}$ EDTA solution using Eriochrome Black T as indicator. A reagent black was titrated and titration in each case was done from deep red to a permanent blue endpoint. The titration value represents both calcium and magnesium ions in the test sample. A repeat titration was done $\mathrm{Ca}^{2+}$ alone in the test samples, $10 \% \mathrm{NaOH}$ was used in place of the ammonium buffer and solochrome dark blue indicator in place of Eriochrome Black T. At $\mathrm{pH}$ of $12.0 \mathrm{Ca}^{2+}$ complexes with EDTA. \% Ca and $\mathrm{Mg}=(100 / \mathrm{W}) * \mathrm{EW}^{*} \mathrm{~N} *(\mathrm{Vf} / \mathrm{Va}) * \mathrm{~T}-\mathrm{B}$. Where, $\mathrm{W}=$ weight of the sample analysed. $\mathrm{EW}=$ Equivalent weight. $\mathrm{N}=$ Normality of EDTA. $\mathrm{Vf}=$ total volume of extract. $\mathrm{Va}=$ volume of extract titrated. $\mathrm{T}=$ titre value of sample. $\mathrm{B}=$ titre value of blank.

\section{Determination of Potassium and Sodium}

Flame photometry was used to determine the concentration of $\mathrm{K}$ and Na. Photometer was set up, switched on and allowed to stay for about 10min. The gas and air inlets were opened and the start knob was adjusted to a non-luminous flame. Meanwhile, standard K and Na sol was prepared separately and each diluted to conc 2, 4, 6, 8 and 10ppm. The appropriate conc filter was selected for $\mathrm{K}$ and $\mathrm{Na}$. The highest conc standard sol was aspirated and its emission intensity adjusted to 100 units. Therefore, starting with the least conc. (2ppm), each standard sol was aspirated and caused to spray over the non-luminous butane gas flame. The emission 
intensity read directly on the instrument and the readings were recorded. Then the samples digests were also aspirated and their reading taken. The emission intensities of the standards were plotted against their conc to obtain a standard curve (calibration graph) for each element. Subsequently, the optical density emission recorded from each of the samples was matched against those in the curve to extrapolate the quantity of each potassium and sodium ions in the sample. The experiment was repeated three times to get a mean concentration. The conc of the test minerals were calculated as follows: $\% \mathrm{~K}$ or $\mathrm{Na}(\mathrm{mg} / 100 \mathrm{~g})=$ $(100 / \mathrm{W}) *(1 / 1000) * \mathrm{X} *(\mathrm{Vf} / \mathrm{Va}) * \mathrm{D}$. where, $\mathrm{W}=$ weight of sample used. $\mathrm{X}=$ concentration $(\mathrm{ppm})$ from curve. $\mathrm{Vf}=$ total volume of extract. $\mathrm{Va}=$ volume of extract (digest) flamed. $\mathrm{D}=$ dilution factor where applicable.

\section{Determination of Vitamins}

The spectrophotometric method was employed. ${ }^{(25)}$

\section{Determination of Vitamin $B_{1}$ (thiamine)}

$5 \mathrm{~g}$ of each sample was homogenized with $50 \mathrm{ml}$ of $1 \mathrm{~N}$ ethanolic $\mathrm{NaOH}$ and filtered. $10 \mathrm{ml}$ of the filtrate was treated with equal vol. of $0.1 \mathrm{~N} \mathrm{~K}_{2} \mathrm{Cr}_{2} \mathrm{O}_{7} \mathrm{sol}$ in a flask. Meanwhile, standard thiamine sol. was also treated with $10 \mathrm{ml}$ of dichromate sol $\left(\mathrm{K}_{2} \mathrm{Cr}_{2} \mathrm{O}_{7}\right)$ in a separate flask while reagent blank was set up by treating $10 \mathrm{ml}$ of the ethanolic $\mathrm{NaOH}$ with the potassium dichromate sol. The absorbance of the sample and the standard sol were measured in a spectrophotometer at wavelength of $360 \mathrm{~nm}$ with the reagent blank used to calibrate the instrument at zero. The thiamine content was calculated thus: $\mathrm{mg} / 100 \mathrm{mg}=$ $(100 / \mathrm{W}) *(\mathrm{Au} / \mathrm{As}) * \mathrm{C} *(\mathrm{Vf} / \mathrm{Va}) * \mathrm{D}$. where, $\mathrm{W}=$ weight of sample analyzed. $\mathrm{Au}=$ absorbance of sample. As $=$ absorbance of standard thiamine solution. $\mathrm{C}=$ conc. standard thiamine solution. $\mathrm{Vf}=$ total volume of filtrate. $\mathrm{Va}=$ volume of filtrate analyzed. $\mathrm{D}=$ dilution factor where applicable.

\section{Determination of Vitamin $B_{3}$ (niacin)}

$5 \mathrm{~g}$ of each sample was treated with $50 \mathrm{ml}$ of $1 \mathrm{~N}$ sulphuric acid and shaken for $30 \mathrm{~min}$. The mixture was further treated with 2 drops of aqueous ammonia, mixed well and then filtered. Standard niacin (nicotinic acid) sol was prepared and diluted as desired. The $10 \mathrm{ml}$ portion of the standard sol as well as the sample extract and $10 \mathrm{ml}$ of the acid sol (treated with a drop of ammonia) were dispersed into separate flasks to serve as standard, sample and reagent blank respectively. Each of them was treated with $5 \mathrm{ml}$ of normal $\mathrm{KCN}$ sol and acidified with $0.02 \mathrm{~N}$ $\mathrm{H}_{2} \mathrm{SO}_{4}$ sol, after which its absorbance was read in a spectrophotometer at a wavelength of 470 $\mathrm{nm}$. The reagent is blank to calibrate the instrument at zero. Niacin content was calculated using the formula: Niacin $\mathrm{mg} / 100 \mathrm{mg}=(100 / \mathrm{W}) *(\mathrm{Au} / \mathrm{As}) * \mathrm{C} *(\mathrm{Vf} / \mathrm{Va}) * \mathrm{D}$. where, $\mathrm{W}=$ weight of sample analyzed. $\mathrm{Au}=$ absorbance of sample. As $=$ absorbance of standard thiamine solution. $\mathrm{C}=$ conc. standard thiamine solution. $\mathrm{Vf}=$ total volume of filtrate. $\mathrm{Va}=$ volume of filtrate analyzed. $\mathrm{D}=$ dilution factor where applicable.

\section{Determination of Vitamin $\mathbf{B}_{2}$ (Riboflavin)}

$5 \mathrm{ml}$ of each sample was dispersed in $100 \mathrm{ml}$ of $5 \%$ ethanol solution in distilled water. The mixture was shaken and filtered. $10 \mathrm{ml}$ of the filtrate was mixed with an equal volume $(10 \mathrm{ml})$ of $5 \%$ potassium permanganate $\left(\mathrm{K}_{2} \mathrm{MnO}_{4}\right)$ solution $10 \mathrm{ml}$ of $30 \%$ hydrogen peroxide $\left(\mathrm{H}_{2} \mathrm{O}_{2}\right)$ was added to it. The above treatment was also given to a $10 \mathrm{ml}$ portion of standard riboflavin 
solution as well as reagent blank. All the flasks (standard, blank, and sample) were meant to stand over a water bath for half an hour and $2 \mathrm{ml}$ of $40 \% \mathrm{Na}_{2} \mathrm{SO}_{4}$ solution was added to each of them. This was made upto $50 \mathrm{ml}$ in a volumetric flask. Their respective absorbance (standard and sample) were measured in a spectrophotometer at $510 \mathrm{~nm}$ wavelength. Readings were taken with the reagent blank at zero. Thus riboflavin content was calculated as: $\mathrm{mg} / 100 \mathrm{mg}=$ $(100 / \mathrm{VW})^{*}(\mathrm{Au} / \mathrm{As})^{*} \mathrm{C} *(\mathrm{Vf} / \mathrm{Va}) * \mathrm{D}$. $\mathrm{W}=$ weight of sample analyzed. $\mathrm{V}=$ volume of sample. $\mathrm{Au}=$ absorbance of sample. As= absorbance of standard thiamine solution. $\mathrm{C}=$ conc. standard thiamine solution. $\mathrm{Vf}=$ total volume of filtrate. $\mathrm{Va}=$ volume of filtrate analyzed. $\mathrm{D}=$ dilution factor where applicable.

\section{Statistical analysis}

All data from the analysis of the seed, leaves, stem, stem bark, root and root bark samples were subjected to statistical analysis system (SSA, 2000) software package. ANOVA was done and means of separation using Fisher Least Significant Difference (LSD).

\section{RESULTS}

The result of the qualitative phytochemical analysis of the seed, leaves, stem, stem bark, root bark and root of $A$. africana is shown below:

Table 1: Qualitative phytochemical constituent of different parts of Afzelia africana

\begin{tabular}{lllllll}
\hline Extracts & Seeds & Leaves & Stem bark & Stem & Root bark & Root \\
\hline Saponin & + & ++ & ++ & + & ++ & + \\
Flavonoid & + & ++ & ++ & + & ++ & + \\
Tannin & ++ & ++ & ++ & + & + & + \\
Steroid & ++ & ++ & + & + & + & ++ \\
Phenol & ++ & ++ & + & + & ++ & + \\
Alkaloid & + & ++ & ++ & + & ++ & + \\
\hline
\end{tabular}

$++=$ present $+=$ slightly present

The quantitative analysis result showed that the phytochemical constituents are all present in the leaves, while they are slightly present in the stem.

Table 2: Percentage proximate constituent of different parts of Afzelia africana

\begin{tabular}{lllllll}
\hline Sample & Seed & Leaf & Stem bark & Stem & Root bark & Root \\
\hline Protein & $3.21 \pm 0.10 \mathrm{e}$ & $2.04 \pm 0.09 \mathrm{~d}$ & $1.46 \pm 0.10 \mathrm{c}$ & $0.59 \pm 0.09 \mathrm{a}$ & $1.11 \pm 0.10 \mathrm{~b}$ & $0.76 \pm 0.10 \mathrm{a}$ \\
Fat & $5.09 \pm 0.11 \mathrm{f}$ & $2.95 \pm 0.07 \mathrm{e}$ & $2.49 \pm 0.06 \mathrm{~d}$ & $0.79 \pm 0.06 \mathrm{a}$ & $2.03 \pm 0.11 \mathrm{c}$ & $1.17 \pm 0.04 \mathrm{~b}$ \\
Fibre & $3.61 \pm 0.06 \mathrm{a}$ & $10.9 \pm 0.33 \mathrm{~b}$ & $36.25 \pm 0.24 \mathrm{~d}$ & $61.1 \pm 0.23 \mathrm{f}$ & $33.50 \pm 0.33 \mathrm{c}$ & $56.97 \pm 0.98 \mathrm{e}$ \\
Ash & $4.35 \pm 0.07 \mathrm{e}$ & $2.89 \pm 0.03 \mathrm{~d}$ & $2.60 \pm 0.06 \mathrm{c}$ & $1.96 \pm 0.08 \mathrm{ab}$ & $2.21 \pm 0.04 \mathrm{~b}$ & $2.03 \pm 0.08 \mathrm{a}$ \\
Moisture & $8.41 \pm 0.03 \mathrm{c}$ & $6.69 \pm 0.03 \mathrm{a}$ & $7.60 \pm 0.03 \mathrm{a}$ & $6.65 \pm 0.07 \mathrm{a}$ & $7.57 \pm 0.08 \mathrm{~b}$ & $6.71 \pm 0.23 \mathrm{a}$ \\
Carbohydrate & $75.33 \pm 0.36 \mathrm{e}$ & $74.50 \pm 0.29 \mathrm{e}$ & $49.60 \pm 0.24 \mathrm{c}$ & $28.91 \pm 0.23 \mathrm{a}$ & $53.61 \pm 0.03 \mathrm{~d}$ & $32.36 \pm 1.36 \mathrm{~b}$ \\
\hline
\end{tabular}

Results are reported in mean \pm SD. Means with same letter in a row are not significantly different $(P>.05)$ 
The result showed that most of the parts contained more carbohydrate, with the seed having the highest content $(75.33 \pm 0.36)$, followed by the leaf, root bark, stem bark, root, and the stem. The highest constituent of the root is fibre $(56.97 \pm 0.98)$, with root having the lowest fibre content (3.61 \pm 0.06$)$.

Table 3: Percentage vitamin constituent of different parts of Afzelia africana

\begin{tabular}{lllllll}
\hline Sample & Seed & Leaf & Stem bark & Stem & Root bark & Root \\
\hline Thiamine & $0.06 \pm 0.02 \mathrm{c}$ & $0.07 \pm 0.005 \mathrm{~d}$ & $0.05 \pm 0.002 \mathrm{~b}$ & $0.01 \pm 0.002 \mathrm{a}$ & $0.06 \pm 0.002 \mathrm{bc}$ & $0.02 \pm 0.002 \mathrm{a}$ \\
Riboflavin & $0.21 \pm 0.005 \mathrm{~b}$ & $0.31 \pm 0.005 \mathrm{c}$ & $0.40 \pm 0.005 \mathrm{~d}$ & $0.00 \pm 0.00 \mathrm{a}$ & $0.40 \pm 0.005 \mathrm{~d}$ & $0.00 \pm 0.00 \mathrm{a}$ \\
Niacin & $0.11 \pm 0.006 \mathrm{~b}$ & $0.42 \pm 0.005 \mathrm{e}$ & $0.18 \pm 0.16 \mathrm{c}$ & $0.07 \pm 0.019 \mathrm{a}$ & $0.20 \pm 0.006 \mathrm{~d}$ & $0.04 \pm 0.005 \mathrm{~b}$ \\
Ascorbic & $4.89 \pm 1.02 \mathrm{bc}$ & $12.91 \pm 1.02 \mathrm{bc}$ & $5.87 \pm 1.02 \mathrm{c}$ & $2.93 \pm 1.02 \mathrm{ab}$ & $5.87 \pm 1.02 \mathrm{c}$ & $2.64 \pm 1.24 \mathrm{a}$ \\
acid & & & & & & \\
\hline
\end{tabular}

Results are reported in mean \pm SD. Means with same letter in a row are not significantly different $(P>.05)$

The table above showed that there is high content of thiamine in all parts of Afzelia africana with the highest found in the leaf $(12.91 \pm 1.02)$ and lowest in the root $(2.64 \pm 1.24)$. Niacin content is high in the leaf $(0.42 \pm 0.005)$ and low in the root $(0.04 \pm 0.005)$. Riboflavin was absent in the stem and root but present in other parts of the plant. Thiamine is high in the leaf $(0.07 \pm 0.005)$ and low in the stem $(0.01 \pm 0.002)$.

Table 4: Percentage quantitative phytochemical constituent of different parts of Afzelia africana

\begin{tabular}{lllllll}
\hline Sample & Seed & Leaf & Stem bark & Stem & Root bark & Root \\
\hline Alkaloid & $0.02 \pm 0.03 \mathrm{~b}$ & $1.41 \pm 0.03 \mathrm{e}$ & $1.12 \pm 0.04 \mathrm{~d}$ & $0.13 \pm 0.01 \mathrm{a}$ & $0.065 \pm 0.01 \mathrm{c}$ & $0.11 \pm 0.01 \mathrm{a}$ \\
Saponin & $0.17 \pm 0.02 \mathrm{c}$ & $0.35 \pm 0.01 \mathrm{e}$ & $0.21 \pm 0.02 \mathrm{~d}$ & $0.07 \pm 0.01 \mathrm{a}$ & $0.23 \pm 0.01 \mathrm{~d}$ & $0.11 \pm 0.01 \mathrm{~b}$ \\
Flavonoid & $0.15 \pm 0.01 \mathrm{~b}$ & $0.37 \pm 0.01 \mathrm{e}$ & $0.23 \pm 0.01 \mathrm{~d}$ & $0.11 \pm 0.01 \mathrm{a}$ & $0.43 \pm 0.02 \mathrm{f}$ & $0.19 \pm 0.02 \mathrm{c}$ \\
Tannin & $0.22 \pm 0.00 \mathrm{c}$ & $0.32 \pm 0.00 \mathrm{f}$ & $0.22 \pm 0.00 \mathrm{e}$ & $0.12 \pm 0.00 \mathrm{~b}$ & $0.19 \pm 0.00 \mathrm{~d}$ & $0.11 \pm 0.00 \mathrm{a}$ \\
Phenol & $0.22 \pm 0.00 \mathrm{c}$ & $0.72 \pm 0.00 \mathrm{f}$ & $0.57 \pm 0.00 \mathrm{~d}$ & $0.18 \pm 0.00 \mathrm{a}$ & $0.68 \pm 0.00 \mathrm{e}$ & $0.20 \pm 0.00 \mathrm{~b}$ \\
Phytate & $0.40 \pm 0.03 \mathrm{~d}$ & $0.37 \pm 0.02 \mathrm{~d}$ & $0.45 \pm 0.01 \mathrm{e}$ & $0.11 \pm 0.01 \mathrm{a}$ & $0.27 \pm 0.01 \mathrm{c}$ & $0.15 \pm 0.02 \mathrm{~b}$ \\
HCN & $7.60 \pm 0.02 \mathrm{~d}$ & $12.99 \pm 0.03 \mathrm{f}$ & $9.05 \pm 0.15 \mathrm{e}$ & $2.33 \pm 0.14 \mathrm{a}$ & $6.74 \pm 0.22 \mathrm{c}$ & $3.00 \pm 0.07 \mathrm{~b}$ \\
Steroid & $0.13 \pm 0.01 \mathrm{c}$ & $0.16 \pm 0.00 \mathrm{~d}$ & $0.05 \pm 0.01 \mathrm{a}$ & $0.04 \pm 0.01 \mathrm{a}$ & $0.07 \pm 0.01 \mathrm{~b}$ & $0.49 \pm 0.01 \mathrm{e}$ \\
Anthocyanin & $0.07 \pm 0.01 \mathrm{a}$ & $0.11 \pm 0.01 \mathrm{~b}$ & $0.09 \pm 0.01 \mathrm{~b}$ & $0.05 \pm 0.01 \mathrm{a}$ & $0.11 \pm 0.01 \mathrm{~b}$ & $0.05 \pm 0.01 \mathrm{a}$ \\
Iridiod & $0.03 \pm 0.01 \mathrm{ab}$ & $0.07 \pm 0.01 \mathrm{~d}$ & $0.04 \pm 0.00 \mathrm{bc}$ & $0.02 \pm 0.01 \mathrm{a}$ & $0.05 \pm 0.01 \mathrm{c}$ & $0.030 .01 \mathrm{ab}$ \\
\hline Resuls
\end{tabular}

Results are reported in mean \pm SD. Means with same letter in a row are not significantly different $(P>.05)$

Quantitative phytochemical analysis in the above samples of Afzelia africana shows that leaf has the highest content of almost all the phytochemical constituents except flavonoid which is high in the root bark $(0.43 \pm 0.02)$, phytate which high in the stem bark $(0.45 \pm 0.01)$ and steroid which is high in the root $(0.49 \pm 0.01)$. 
Table 5: Percentage mineral content of different parts of Afzelia africana

\begin{tabular}{lllllll}
\hline Sample & Seed & Leaf & Stem bark & Stem & Root bark & Root \\
\hline Calcium & $188.80 \pm 5.4 \mathrm{c}$ & $28.84 \pm 0.25 \mathrm{a}$ & $35.87 \pm 2.02 \mathrm{~b}$ & $36.81 \pm 1.20 \mathrm{~b}$ & $34.11 \pm 1.74 \mathrm{~b}$ & $31.93 \pm 2.02 \mathrm{ab}$ \\
Magnesium & $10.04 \pm 0.97 \mathrm{c}$ & $9.06 \pm 0.24 \mathrm{bc}$ & $10.08 \pm 0.94 \mathrm{c}$ & $5.04 \pm 0.14 \mathrm{a}$ & $7.65 \pm 2.19 \mathrm{~b}$ & $4.96 \pm 0.14 \mathrm{a}$ \\
Potassium & $137.33 \pm 1.15 \mathrm{~b}$ & $368.67 \pm 3.06 \mathrm{f}$ & $210.67 \pm 2.31 \mathrm{~d}$ & $109.33 \pm 6.35 \mathrm{a}$ & $187.00 \pm 6.35 \mathrm{c}$ & $223.33 \pm 3.79 \mathrm{e}$ \\
Sodium & $11.63 \pm 0.40 \mathrm{~d}$ & $9.01 \pm 0.09 \mathrm{~b}$ & $9.89 \pm 0.39 \mathrm{c}$ & $5.33 \pm 0.23 \mathrm{a}$ & $9.35 \pm 0.67 \mathrm{c}$ & $5.23 \pm 0.23 \mathrm{a}$ \\
Phosphorus & $40.33 \pm 1.50 \mathrm{a}$ & $440.33 \pm 6.66 \mathrm{f}$ & $230.67 \pm 2.52 \mathrm{e}$ & $112.00 \pm 4.00$ & $191.33 \pm 3.06 \mathrm{~d}$ & $104.67 \pm 4.62 \mathrm{~b}$
\end{tabular}

Results are reported in mean \pm SD. Means with same letter in a row are not significantly different $(P>.05)$

Mineral analysis of different parts of Afzelia africana showed that phosphorus content is high in the leaf $(440.33 \pm 6.66)$ and low in the seed $(40.33 \pm 1.50)$. Potassium was also observed to be more in the leaf $(368.67 \pm 3.06)$ and low in the stem $(109.33 \pm 6.35)$. Calcium content is higher in the seed (188.80 \pm 5.4$)$ and lower in the leaf $(28.84 \pm 0.25)$. Magnesium content was higher in the stem bark $(10.08 \pm 0.94)$ and lower in the root $(4.96 \pm 0.14)$. Sodium was higher in the seed $(11.63 \pm 0.40)$ and lower in the stem $(5.33 \pm 0.23)$.

\section{DISCUSSION AND CONCLUSION}

The analysis of the approximate composition of different parts of A. africana showed that fat content was highest in the seed (5.09 \pm 0.11 ). According to Mary and Garvin (2008), fats in the seed could be used in maintaining healthy skin and hair temperature. The crude fibre was high in stem $(61.1 \pm 0.23)$ and low in the seed (3.61 \pm 0.06$)$. Thus, A. africana may be an effective source of dietary fibre which is important for reducing cholesterol levels in the body so as to minimize risk of cardiovascular disease caused by high cholesterol ${ }^{(29)}$. It also adds bulk to the diet and prevents the intake of excess starchy food ${ }^{(22)}$ and may therefore guard against metabolic conditions such as hypercholesterolemia and diabetes mellitus. ${ }^{(12)}$ Carbohydrates play major roles in mediating interactions among and between cells and other element in the environment ${ }^{(28)}$. They also serve as storage and transport systems. The high protein, fat and carbohydrate of $A$. africana in seed is desirable in foods. While protein is important in regeneration of cells, fats in diets keep the body warm by insulation and also act as solvent for vitamins. Ash content is a holistic representation of the total of the total mineral in foods. (26) The results obtained from this research shows that the major constituents were higher in the seeds than other parts of the plant. Also, the distribution of these components in the various parts of the plants is attributed to the translocation of synthesized plant constituents in the different storage parts.

The distribution of vitamins in the plant shows high conc. in the leaf and seed whereas the woody parts of stem and roots contain little of the vitamins. The vitamins studied could be used for maintaining normal growth, digestion, and metabolism of protein, fats, carbohydrate and mineral utilization. 
The mineral analysis in different parts of the plant showed high levels of phosphorus, potassium and calcium. Calcium (188.80/100g) and Potassium $(368.67 \mathrm{mg} / 100 \mathrm{~g})$ were highest in the seed and least in the leaf. The results indicate that all parts of the plant tested have the potential of having good medicinal roles. Potassium, sodium and magnesium are important electrolytes which help in osmoregulation to maintain good homeostasis. Intake of calcium is known to aid bone and teeth formation. ${ }^{(20)}$

According to the result shown in table 4, the conc. of phytochemicals in the tested plant parts showed significant difference. The presence of these secondary metabolites accounts for the usefulness of its part for medicinal purposes. ${ }^{(9)}$ Alkaloid which was found to be highest in the leaf $(1.41 \pm 0.03)$ and least in the root $(0.11 \pm 0.01)$, are known to be toxic and can have effect on the human physiology ${ }^{(1)}$, but another study observed that alkaloids are recognized more for their pharmacological activities rather than toxicity. Flavonoids are antioxidants which can protect the body against oxidative cell destruction, they have also shown to be antibacterial, anti-inflammatory, antiviral and antineoplastic activity. ${ }^{(1)}$ Statistically, the differences in the flavonoid content of different parts of A. Africana, are significant. Saponin is seen to be more in the leaf $(0.35 \pm 0.01)$ and least in the stem $(0.07 \pm 0.01)$, they are antimicrobial that favorably influences oral health ${ }^{(15)}$, it also supports kupffer cell in the liver and encourages normal detoxification. Tannins were also found in all plant parts studied, they are used to treat intestinal disorders such as diarrhea and dysentery thus exhibiting antimicrobial activity. It was also observed that tannin is remarkable in cancer prevention. ${ }^{(18)}$

Phytate is highest in the stem bark $(0.45 \pm 0.01)$ and lowest in the stem $(0.11 \pm 0.1)$. It plays an important role in pancreas function and insulin secretion, lowers the blood glucose and lipids, it also inhibits some cancer cells by depriving them of the minerals they need. The deprivation of essential minerals like iron would serve as a broad treatment for cancer. ${ }^{(13)}$ High levels of phytate and $\mathrm{HCN}$ are known as anti-nutritive factors that limit the use of many plants for either food or medicinal purposes because they elicit deleterious effects on man and animals. ${ }^{(16)}$

In general, there is a wide variation in the accumulation of the different phytochemicals in the different plant parts. This finding underscores the observation that different part of the plant is employed in traditional medical formulas

\section{REFERENCES}

[1]. Alan, L and Miller, N. D. (1996). Antioxidant flavonoids: structure, function and chemical usage. Alternative Medical Review 1: 103-111

[2]. Bemiller, N. J. (2003). Carbohydrate analysis. In: SS. Nielson (Edn.) Food Analysis. $3^{\text {rd }}$ edition, Kluwer Academic/Plenum Publishers, New York. Pp. 143-174

[3]. Boham, B. A. and Kocopai, A. R. (1994). Flavonoids and condensed Tannins from Leaves of Hawaiian Vaccinium vaticulatum and V. Calycinium. Pacific Science. 48: 458-463

[4]. Bradley, R. Y. (2003). Moisture and Total Solid Analysis. In: SS. Nielson (Edn.) Food Analysis. $3^{\text {rd }}$ edition, Kluwer Academic/Plenum Publishers, New York. Pp. 83-85

[5]. Bruneton, J. (1999). Pharmacognosy, phytochemistry and medicinal plants. Second edition, Lavoiser publishing, France. Pp 1119

[6]. Carpenter, C. E. and Hendricks, D. G. (2003). Mineral analysis. In: SS. Nielson (Edn.) Food Analysis. $3^{\text {rd }}$ edition, Kluwer Academic/Plenum Publishers, New York. Pp. 195 
[7]. Chang, S. K. C. (2003). Protein analysis. In: SS. Nielson (Edn.) Food Analysis. $3^{\text {rd }}$ edition, Kluwer Academic/Plenum Publishers, New York. Pp. 83-85p

[8]. Cheng, G. and Breen, P. (1991). Activity of Phenylalanine ammonia-lyase (PAL) and conc. of anthocyanins and phenolics in developing strawberry fruit. Journal of American Society for Horticultural Science. 116(5): 865-869

[9]. Ebana, R. U; Essien, A. I and Ekpa, O. D. (1995). Nutritional and Potential medicinal value of the leaves of Lasianthra Africana (Beauv.) Global Journal of Pure and Applied Sciences 1: 1-8

[10]. Harbers, H. L. and Nielson, S. S. (2003). Ash analysis. In: SS. Nielson (Edn.) Food Analysis. $3^{\text {rd }}$ edition, Kluwer Academic/Plenum Publishers, New York. Pp. 103-112

[11]. Harborne, J. B. (1973). Textbook of phytochemical methods. Chapman and Hall Ltd., London. Pp 49-188

[12]. Henry, S. (2004). Fiber: An all natural "medicine” for type 2 diabetes? Consumer Health Interactive. www.ahealthyme.com re-accessed 13/8/17

[13]. Hunell, R. F. (2003). Influence of vegetable protein sources in trace element and mineral bio-availability. J. Nutr 133(297): 35-75

[14]. Igwenyi, I. O; Offor, C. E; Aja, P. M; Aloh, G. S; Orji, O. U and Afiukwa, C. A. (2011). Potential of Afzelia africana vegetable oil in biodiesel production. Asian Journal of Biochemistry 6(6): 450-457

[15]. Just, M. J; Recio, M. C; Giner, R. M; Cueller, M. J; Manez, S; Bilia, A. R and Rios, J. L. (1998). Anti-inflammatory activity of unusual lupine saponins from Bupleurum frutiscens. Plant Medicine 64: 404-407

[16]. Kubmarawa, D; Adeanya, I. F. H; and Magomya, A. M. (2008). Amino acid profile of two non-conventional leafy vegetables: Sesamum and Balanitesta egyptiaca. Afri $J$ of Biotechnology 7(19): 3502-3504

[17]. Lewis, W. H. and Elwis-Lewis, M. P. F. (1997). Medical Botany. Plants affect man's health. John Wiley and sons, New York. Pp 515

[18]. Li. H; Wang, Z and Liu, Y. (2003). Review in the tannin activity of cancer prevention and anticancer. Zhong-Yao-Cai 26 (6): 444-448

[19]. Madukwe, E. U; Mefoh, N. C. and Obizoba, I. C. (2013). Chemical, nutritive and organoleptic attributes of fermented Afzelia Africana tender leaves and shoots. International Journal of Scientific Research 3(8): 1-8

[20]. Manu, R; Shefali, S and Amit, K. T. (2013). Calcium and Oral Health: A Review. International Journal of Scientific Research 2(9): 23-30

[21]. Mary, L and Garvin, M. D. (2008). Learning about Fats: Encyclopedia of fats C. R. C. hall, USA. Pp 50

[22]. Mensah, J. K; Okoli, R. I; Oha-Obodo, J. O and Eifediyi, K. (2008). Phytochemical, nutritional and medicinal properties of some leafy vegetables consumed by Edo people of Nigeria. Afr. J. of Biotechnology 7 (14): 2304-2309

[23]. Min, D. B. and Boff, J. M. (2003). Crude Fat Analysis. In: SS. Nielson (Edn.) Food Analysis. $3^{\text {rd }}$ edition, Kluwer Academic/Plenum Publishers, New York. Pp. 113-130

[24]. Okeke, C. U. and Elekwa, I. (2006). Proximate and preliminary phytochemical analysis of avocado pear (Persea gratissima) Gaertn. Nigerian Journal of Botany 19: 156-162

[25]. Okwu, D. E. (2004). Chemical composition of Spondias mombin Linn plant parts. Journal of Sustain Agricultural Environment 6(2): 140-147

[26]. Onwuka, G. F (2005). Food analysis and instrumentation theory and practice. Naphthali print, a division of A. A. support Nigeria Ltd 
[27]. Pearson, D. (1976). Chemical analysis of food. Church-hill Livingstone Edinburgh, UK. Pp 103-110

[28]. Raven, P. H and Johnson, G. B. (1999). Antioxidant activities of flavonoids as bioactive components of food. Biochemical Sociology Translation 24: 790-795

[29]. Umoh, I B. (1998). Commonly used fruits in Nigeria. Benin Post-harvest Research Unit, Department of Biochemistry of Benin 1: 84-30

[30]. Yascin, F. N; Kaya, D; Calis, T; Ersoz, E and Palaska, M. (2008). Determination of iridiod glycoside from four Turkish Laminium species. Turkish Journal of Chemistry 32: 457487 